\title{
Research on the Investment Value Evaluation Index System of Listed Real Estate Companies
}

\author{
Pengyi Wang* \\ School of Economics and Management, Beijing Jiaotong University, Beijing, China, 100044 \\ ${ }^{*}$ Corresponding author. Email:18526282039@163.com
}

\begin{abstract}
Scientific, reasonable and accurate analysis and evaluation of the investment value of listed companies is of great significance to investors, and financial information is the most important and direct way to understand the enterprise, through the analysis of financial statements can basically understand the financial situation of an enterprise. However, the financial information content of enterprises is complex, and there are hundreds of financial indicators alone. Therefore, this article combines the unique characteristics of listed real estate companies to randomly select 48 listed real estate companies in Shanghai and Shenzhen, and select the most commonly used and important 16 financial indicators, using the method of factor analysis, summarize the various and complex financial indicators into several important factors, and establish an investment value evaluation index system to facilitate investors' decision-making.
\end{abstract}

Keywords: Listed real estate companies, Investment value, Financial indicators, Factor analysis.

\section{INTRODUCTION}

Since 2004, China's real estate market has ushered in tremendous development. As an important growth point of China's economy, real estate has not only played a huge role in promoting the growth of GDP, but also promoted the urbanization process in China. However, in recent years, with the implementation of various government regulatory policies, China's real estate industry has temporarily entered the cooling phase, the corresponding share prices of listed companies have also been affected to a certain extent. However, according to the survey report on population and housing, China's population is still in further growth, the continued growth of the population also creates space for housing growth, therefore, the real estate industry is still an industry with investment value in the next period of time. Against this backdrop, this article analyses the financial indicators of these listed real estate companies, hoping to provide some reference value for investors.

\subsection{Research Purpose}

The purpose of this paper are as follows: first, to help users of financial statements understand the comprehensive business situation of an enterprise more clearly and easily, and avoid the interference of useless data; second, to assist investors to make correct investment choices and avoid unnecessary risks as much as possible; third, to help enterprise managers to exercise proper control over the daily business activities of the enterprise.

\subsection{Literature Review}

In the empirical study of financial indicators, the West started earlier than the domestic research. In the mid-20th century, Drucker, a famous management scientist, proposed eight indicators for evaluating the performance of a company by means of empirical research, which laid the foundation for the establishment of the indicator system later on. Using factor analysis, Michael, Pitchels and Carruthers studied the financial indicators of 221 companies over four years, 1951, 1957, 1963 and 1969, and divided the company's 48 financial indicators into seven groups. In 2001, Kumar analysed a large number of data from the U.S. securities market and found that factor analysis methods were more suitable for analysing the financial data of these companies to study their investment value.

Throughout China, in recent years, there also have been many articles on the analysis and research about investment value index of listed companies in different industries. In 2009, Tian Lu selected 44 new energy listed companies and intercepted 15 financial indicators 
using SPSS' main component analysis methods to objectively evaluate the performance of these companies. At the same time, in addition to starting from the perspective of financial indicators, some scholars have proposed to pay attention to non-financial indicators, because it reflects the value creation process, can measure the long-term ability of enterprises to create value, so that it and financial indicators combined to build a comprehensive evaluation index system is very valuable.

\section{METHODS}

This paper adopts the method of factor analysis in statistics. Factor analysis seeks to replace the original data information with as few factors as possible, reduce the correlation between the original variables, and simplify the complex model into a simpler model to facilitate the researcher's analysis of the survey questions. This paper uses SPSS 17.0 to analyze and process this data. Import the data from Excel into SPSS, select the factor analysis method in downscaling, and complete the work task by setting some options.

This paper selects 48 listed companies from A-shares in Shanghai and Shenzhen, which have been listed relatively early, have certain financial strength and are comparable. This paper selects the data indicators of the financial statements of major companies in 2019, which can better examine the recent business conditions of the real estate industry. These companies include Vanke A, Royal Court International, Lujiazui and so on. In addition, this paper has selected 16 financial indicators covering five aspects: debt-paying ability, operation capacity, profitability, development capacity and stock value, which can basically reflect the financial situation of the companies, these indicators are shown in the following table (The data in this article are from the CSMAR database).
Table 1. Evaluation index of investment value of real estate listed companies

\begin{tabular}{|c|c|}
\hline Evaluation projects & Evaluation indicators \\
\hline \multirow{4}{*}{ Debt-paying ability } & Current ratio \\
\cline { 2 - 2 } & Quick ratio \\
\cline { 2 - 2 } Development capacity & Debt-to-equity ratio \\
\cline { 2 - 2 } & Debt-to-long capital ratio \\
\cline { 2 - 2 } Operation capacity & Total assets growth rate \\
\cline { 2 - 2 } & Net profit growth rate \\
\hline \multirow{5}{*}{ Profitability } & Current assets turnover \\
\cline { 2 - 2 } & Total assets turnover \\
\hline & Asset profit ratio \\
\hline & Return on total assets rate \\
\cline { 2 - 2 } & Return on equity \\
\hline \multirow{4}{*}{ Stock value } & Earning per share \\
\cline { 2 - 2 } & Net assets per share \\
\cline { 2 - 2 } & Retained earning per share \\
\hline
\end{tabular}

\section{RESULTS}

\subsection{Examine the Suitability of the Original Variables for Factor Analysis}

Below are the KMO and Bartlett's test data tables. From the table 2, the Bartlett sphericity test statistic has an observed value of 837.215, and the corresponding probability p-value is close to 0 , indicating that the unit matrix is significantly different from the correlation coefficient matrix. At the same time, theoretically, if the value of KMO is closer to 1 , the better the conditions for factor analysis .But it means that the conditions of the factor analysis are not met if it is less than 0.5 . The KMO value this time was 0.536 , which passed this inspection.

Table 2. KMO and Bartlett's Test

\begin{tabular}{|lrr|}
\hline Kaiser-Meyer-Olkin Measure of Sampling & \\
Adequacy & & .536 \\
Bartlett's Test of & Approx. Chi-Square & 837.215 \\
Sphericity & $\mathrm{df}$ & 120 \\
& Sig. & .000 \\
\hline
\end{tabular}


Table 3. Total variance explained

\begin{tabular}{|c|c|c|c|c|c|c|}
\hline \multirow{2}{*}{ Component } & \multicolumn{3}{|c|}{ Initial Eigenvalues } & \multicolumn{3}{c|}{ Extraction Sums of Squared Loadings } \\
\hline & Total & \% of Variance & Cumulative \% & Total & \% of Variance & Cumulative \% \\
\hline 1 & 5.020 & 31.374 & 31.374 & 5.020 & 31.374 & 31.374 \\
\hline 2 & 3.700 & 23.126 & 54.500 & 3.700 & 23.126 & 54.500 \\
\hline 3 & 2.205 & 13.780 & 68.279 & 2.205 & 13.780 & 68.279 \\
\hline 4 & 1.459 & 9.119 & 77.398 & 1.459 & 9.119 & 77.398 \\
\hline 5 & .995 & 6.216 & 83.614 & & & \\
\hline 6 & .704 & 4.398 & 88.012 & & & \\
\hline 7 & .576 & 3.603 & 91.615 & & & \\
\hline 8 & .498 & 3.113 & 94.728 & & & \\
\hline 9 & .328 & 2.051 & 96.779 & & & \\
\hline 10 & .181 & 1.130 & 97.909 & & & \\
\hline 11 & .140 & .873 & 98.782 & & & \\
\hline 12 & .097 & .604 & 99.386 & & & \\
\hline 13 & .062 & .386 & 99.771 & & & \\
\hline 14 & .020 & 122 & 99.894 & & & \\
\hline 15 & .011 & .071 & 99.965 & & & \\
\hline 16 & .006 & .035 & 100.000 & & & \\
\hline
\end{tabular}

\subsection{Extraction of Public Factors}

From the total variance explained in the table 3 , it can be seen that 4 common factors were extracted this time, and they explained $77.398 \%$ of the total variance of the original variables. In general, the information of the original variables was less lost, and the factor analysis results were more satisfactory.

\subsection{Naming of New Factors}

According to Table 4, the four common factors are named as follows:

The first factor includes the original variables such as return on total assets rate, asset profit ratio, total assets turnover, return on equity, current assets turnover, receivables turnover ratio, which are mainly related to profitability and operating capacity, and can be interpreted as a profitability factor based on asset operations, recorded as $\mathrm{F}_{1}$.

Net assets per share, retained earning per share, earning per share, debt-to-long capital ratio have large loads on the second factor, which is primarily related to the market value of the firm's stock and can be interpreted as a market value factor, recorded as $\mathrm{F}_{2}$.

The third factor contains three original variables, current ratio, quick ratio, debt-to-equity ratio, all of which are indicators related to the firm's ability to pay its debts, and can be named the debt-paying factor, denoted $\mathrm{F}_{3}$.

Total assets growth rate, net assets growth rate, net profit growth rate are highly loaded on the fourth factor, which reflects the growth of the firm, i.e., its ability to develop, and is therefore interpreted as a growth factor and recorded as $\mathrm{F}_{4}$.

\subsection{Calculation of Factor Scores}

According to the component score coefficient matrix (table 5), the variance contribution rate of each factor after rotation is used as the coefficient construction model function, so the final comprehensive score calculation formula is as follows:

$$
\mathrm{F}=0.261 \mathrm{~F} \_1+0.207 \mathrm{~F} \_2+0.161 \mathrm{~F} \_3+0.145 \mathrm{~F} \_4
$$

According to this formula, the 48 companies selected were calculated and ranked. At the same time, sort the net assets per share indicators of these companies, because this indicator reflects the value and position of the company in the market, and is a relatively reference indicator. By comparing the ranking of comprehensive scores and the ranking of net assets per share can observe whether these stocks are overvalued or undervalued. 
Table 4. Rotation component matrix

\begin{tabular}{|c|c|c|c|c|}
\hline & \multicolumn{4}{|c|}{ Component } \\
\hline & 1 & 2 & 3 & 4 \\
\hline $\begin{array}{l}\text { Return on total } \\
\text { assets rate }\end{array}$ & .898 & .221 & -.187 & .047 \\
\hline Asset profit ratio & .856 & .240 & -.140 & .032 \\
\hline Total assets turnover & .831 & -.227 & .222 & .097 \\
\hline Return on equity & .806 & .414 & -.021 & .253 \\
\hline $\begin{array}{l}\text { Current assets } \\
\text { turnover }\end{array}$ & .749 & -.334 & .208 & $\begin{array}{c}-.02 \\
6\end{array}$ \\
\hline $\begin{array}{c}\text { Receivables turnover } \\
\text { ratio }\end{array}$ & .599 & .305 & -.154 & .177 \\
\hline Net assets per share & .010 & .896 & .167 & .013 \\
\hline $\begin{array}{c}\text { Retained earning per } \\
\text { share }\end{array}$ & .178 & .862 & .181 & $\begin{array}{c}-.05 \\
8\end{array}$ \\
\hline Earning per share & .343 & .833 & .178 & .051 \\
\hline $\begin{array}{l}\text { Debt-to-long capital } \\
\text { ratio }\end{array}$ & -.256 & .540 & .504 & .239 \\
\hline Current ratio & -.061 & -.031 & -.840 & $\begin{array}{c}-.06 \\
6\end{array}$ \\
\hline Quick ratio & -.043 & -.191 & -.818 & $\begin{array}{c}-.08 \\
8\end{array}$ \\
\hline Debt-to-equity ratio & -.204 & .448 & .791 & .212 \\
\hline $\begin{array}{c}\text { Total assets growth } \\
\text { rate }\end{array}$ & -.007 & .092 & .241 & .891 \\
\hline $\begin{array}{c}\text { Net assets growth } \\
\text { rate }\end{array}$ & .325 & .002 & .072 & .833 \\
\hline $\begin{array}{l}\text { Net profit growth } \\
\text { rate }\end{array}$ & .051 & -.013 & .037 & .776 \\
\hline
\end{tabular}

\section{CONCLUSION}

This paper conducts a factor analysis of 16 financial indicators of 48 real estate companies, aiming to establish an investment value evaluation model. It is found that the operation ability indicators and profitability indicators of the enterprises are highly correlated, and the two sets of indicators can be referred to each other for a comprehensive analysis. The conclusions of this paper give investors and other report users a reference for determining the investment value of the enterprise, and the model is relatively simple and convenient compared to other analysis methods, and is also basically consistent with the situation in the securities market. Therefore, the model has strong practicality.

But this article also has some unsolved problems. The data selected in this article are only data for the year 2019, which may affect the conclusion of this article to some extent. At the same time, this article only analyses from the perspective of quantitative indicators, and does not incorporate qualitative non-financial data, which may lead to incomplete thinking of problems. These issues will be improved and perfected in future research.

Table 5. Component score coefficient matrix

\begin{tabular}{|c|c|c|c|c|}
\hline & \multicolumn{4}{|c|}{ Component } \\
\cline { 2 - 5 } & 1 & 2 & 3 & 4 \\
\hline Current ratio & -.061 & .115 & -.397 & .083 \\
\hline Quick ratio & -.043 & .053 & -.359 & .070 \\
\hline Debt-to-equity ratio & -.051 & .058 & .277 & .011 \\
\hline $\begin{array}{c}\text { Debt-to-long } \\
\text { capital ratio }\end{array}$ & -.091 & .136 & .119 & .065 \\
\hline $\begin{array}{c}\text { Total assets growth } \\
\text { rate }\end{array}$ & -.064 & -.014 & -.014 & .410 \\
\hline $\begin{array}{c}\text { Net profit growth } \\
\text { rate }\end{array}$ & .116 & .092 & -.105 & .056 \\
\hline $\begin{array}{c}\text { Net assets growth } \\
\text { rate }\end{array}$ & .024 & -.043 & -.055 & .378 \\
\hline $\begin{array}{c}\text { Receivables } \\
\text { turnover ratio }\end{array}$ & -.045 & -.024 & -.079 & .376 \\
\hline $\begin{array}{c}\text { Current assets } \\
\text { turnover }\end{array}$ & .235 & -.199 & .199 & -.095 \\
\hline $\begin{array}{c}\text { Total assets } \\
\text { turnover }\end{array}$ & .241 & -.169 & .179 & -.044 \\
\hline Asset profit ratio & .201 & .052 & -.054 & -.038 \\
\hline $\begin{array}{c}\text { Return on total } \\
\text { assets rate }\end{array}$ & .209 & .049 & -.073 & -.027 \\
\hline Return on equity & .166 & .098 & -.054 & .058 \\
\hline Earning per share & .044 & .254 & -.020 & -.037 \\
\hline Net assets per share & -.046 & .300 & -.050 & -.029 \\
\hline $\begin{array}{c}\text { Retained earning } \\
\text { per share }\end{array}$ & .008 & .276 & -.019 & -.079 \\
\hline
\end{tabular}

\section{REFERENCES}

[1] Li Silei. An empirical study on the subscription of targeted new shares by connected shareholders empirical numbers from the Chinese securities market [D]. Jiangxi: Jiangxi University of Finance and Economics, 2017.

[2] Song Yunfei. An empirical study of the investment value of real estate listed companies [D]. Beijing: University of International Business and Economics, 2006.

[3] Kang Ruzhen. Empirical analysis of the investment value of listed coal companies [D]. Beijing: Renmin University of China, 2009.

[4] Jing Chenyu. Analysis of investment value of listed companies in the new energy industry [D]. Gansu: Lanzhou University, 2018. 
[5] Li Yaling. Factor analysis and investment decision analysis of financial indicators of listed real estate companies[J]. Modern Business,2012(15):66.

[6] Lv Meiyan. Factor Analysis of Financial Indicators of Listed Real Estate Companies[J]. Modern Business, 2011(36):209.
[7] Fama, Eugene F. and Kenneth R French, Multi-factor explanations of asset pricing anomalies[J], Journal of Finance, Vol.51,1996.

[8] M.J. Gombola, J.EKetz. A Note on Cash Flow and Classification-Patterns of Financial Ratios[J]. The Accounting Review, 1993. 